\title{
Groundwater conflicts or disputes? Experience from Mbarali District in Tanzania
}

\author{
Samwel J. Kabote ${ }^{1 \star}$ and Johnson L. Gudaga ${ }^{2}$ \\ ${ }^{1}$ Department of Development Studies, College of Social Sciences and Humanities, Sokoine University of Agriculture, \\ Morogoro, Tanzania. \\ ${ }^{2}$ Department of Community Development, Amani College of Management and Technology, Njombe, Tanzania. \\ Received 12 May, 2018; Accepted 8 June, 2018
}

This article examines conflicts and or disputes attributed to ineffectiveness of groundwater governance. The study adopted sequential exploratory research design. A random sample of $\mathbf{9 0}$ water users was involved in the survey. The key informants and focus group discussions were used to collect qualitative data. Content analysis was used to analyze qualitative data. Frequency and percentage distribution of the responses were computed by using Statistical Package for the Social Sciences (SPSS). The results show that $43(47.7 \%)$ of the sample experienced groundwater disputes, between and or among water users themselves, or between groundwater governance structures, at least in the previous five years since 2013. This is attributed to poor governance and failure of the actors in abiding to the guidelines of the Water Resource Management Acts of 2009 (WRMA), particularly lack of transparency, destruction of water pumps and unequal distribution of water among groundwater users. Some disputes were resolved successfully at water users' level, while those occurred between governance structures were difficult to resolve. The article concludes that there was poor groundwater governance and therefore disputes occurred. The disputes could develop into conflicts if continue unabated. Therefore, the article recommends strengthening of groundwater governance in abiding to the Acts. It also recommends a comprehensive governance structural arrangement, formal and informal institutions to enhance groundwater governance, specifically resolving groundwater disputes to avoid conflicts in future.

Key words: Groundwater, disputes, conflicts, governance, structures, Tanzania.

\section{INTRODUCTION}

The need for groundwater use is globally increasing especially in semi-arid and arid environments where surface water is dwindling mainly because of climate and environmental changes. About $90 \%$ of all accessible freshwater is invisible groundwater found in aquifers (Jarvis, 2008; Earth Security Group, 2016).
As such, aquifers are critical for improving water supply and for the peoples' livelihoods, more generally. This calls for concerted efforts, to put up a framework regarding governance structures and institutions for utilizing groundwater sustainably. The situation of being invisible together with lack of international laws governing

${ }^{*}$ Corresponding author. E-mail: sjkabote@sua.ac.tz.

Author(s) agree that this article remain permanently open access under the terms of the Creative Commons Attribution License 4.0 International License 
shared aquifers suggests misunderstandings in future leading to groundwater conflicts at an international level. Even though, an existing literature on conflicts over groundwater focuses mainly on contamination of wells than groundwater use and boundaries of the aquifers at different levels.

Groundwater use conflicts are not conspicuously reported in the literature. Nevertheless, they unquestionably exist and are likely to increase in the near future because of many factors like increasing demand for groundwater use, inadequate monitoring, lack of understanding of the groundwater resource, ineffectiveness of water governance structures and institutions in managing groundwater, specifically, weak policies, laws and by-laws, and inadequate administrative capacity at a local level (United Nations Environmental Security, 2004; Foster and Garduno, 2013; Robins and Fergusson, 2014; Gudaga et al., 2018a). Other factors include fragmented planning and management, lack of integrated approaches, climate change, conflicting sectoral policies, rapid population increase and economic development (Kweka-Msale and Magina, 2009; Kashaigili, 2010; URT, 2012).

Some writers like Tuinhof et al. (2011) argue that the causes of groundwater use conflicts vary based on the circumstances like drying up water wells, water pollution, and reduction of base flow. This suggests that a well established and strengthened structural and institutional arrangement for groundwater conflict resolution need to be in place at local, national and international level. It is clear from the literature that information on water use conflicts in most Sub-Saharan African countries like Tanzania is mainly about surface than groundwater. For example, a study conducted by Facius (2008) identifies three types of surface water use conflicts: first, irrigation farming conflicts that occur between upstream and downstream users, because the upstream water users are perceived to use too much water; secondly, pastoralists conflicts that occur between one another over the use of wells for cattle; and domestic users conflicts that occur when one user fails to wait for his/her turn when getting water from wells, riverbeds or from taps. The same study shows that the mechanism for conflict resolution involves between the actors when the offender pays a fine to the victim or reconstruct a well. Water conflict resolution also involves governance structures like the Village Council, Water User Associations for issues concerning irrigation, pastoralist groups and households. Households are critical in perpetuating norms, values and behaviour that regulate water use at a household, community and society level. Water Basin offices are rarely involved in resolving water use conflicts in Tanzania.

The concept of conflict is defined very clearly in the literature as disagreement or misunderstanding within, between and or among individuals, groups and governance structures that develops into violent actions including physical fighting (Kweka-Msale and Magina, 2009). The misunderstanding becomes a conflict when it has serious impacts on the parties involved because of poorly managed changes in policy, legal or institutional context, political, economic and social changes. Using this line of thinking, such conflicts become groundwater use conflicts if they occur among or between groundwater users, or between governance structures responsible for groundwater governance. In this article, we consider to be disputes if misunderstanding between the parties does not develop into violent actions. Resolving groundwater conflicts therefore requires adequate technical understanding of the parties involved, the causes and governance structures and institutions critical for addressing them.

In Sub-Saharan African (SSA) countries including Tanzania, customary institutions that include norms, values and attitudes are undoubtedly strong in resolving and preventing surface water conflicts because they are rooted in the local society and therefore respond well to the local water situation than, sometimes, formal institutions. Such informal institutions are in most cases flexible and capable of adjusting ecological uncertainties. In recent years, interactions between groundwater, communities and society particularly in semi-arid and arid environments has increased in SSA including Tanzania (Kashaigili, 2010; Villholth, 2013). This leads to the argument that groundwater use conflicts are certainly inevitable especially if institutions and governance structures to manage groundwater and or water resource in general are not effective to influence groundwater users' behaviour. As it is for surface water, informal institutions like norms, values and attitudes should be applied in groundwater conflict resolution because they appear to be effective regarding water governance (Gudaga et al., 2018a; 2018b). These however, should work simultaneously, but in a coordinated way, with formal institutions like policies, rules and regulations to enhance groundwater governance.

Based on the foregoing introduction, it is clear that the information on groundwater use conflicts is inadequate and fragmented in Tanzania, making it difficult to comprehend and make a sold conclusion. Therefore, this article contributes knowledge to the following issues:

(1) Local level trends in groundwater use conflicts and or disputes

(2) Parties involved in the conflicts or disputes

(3) Causes of the conflicts or disputes and

(5) Actors involved in groundwater use conflict or dispute resolution.

Addressing these issues provides knowledge on groundwater governance in the study area and in Tanzania at large. The article is organized into five sections. Section one set an introduction to the article. Section two presents the methodology used while section 
three describes respondents' characteristics. Section four is devoted to results and discussion and conclusions and policy recommendations are presented in section five.

\section{METHODOLOGY}

The methodology used in this article is as described by Gudaga et al. (2018a; 2018b). The study was conducted in Mbarali District, Mbeya Region. Mbarali is one of the districts that are found in semiarid environment in Tanzania. The reason for selecting the district for study is that it is essential for two things: paddy production and a source of water for Ruaha Great River that serves water to Ruaha National Park ecology. The River is also a source of water for Mtera, Kidatu and Kihansi hydroelectric power plants. All these activities depend on surface water that is dwindling as such the use of groundwater for socio-economic activities like domestic and irrigation is promoted to sustain water in the Ruaha Great River. The district covers an area of 16,632 square kilometres and has a population of 300,517 (URT, 2014). It is located at latitude $8^{\circ} 51^{\prime}$ $\left(8.85^{\circ}\right) \mathrm{S}$, longitude $33^{\circ} 51^{\prime}\left(33.85^{\circ}\right) \mathrm{E}$. Altitude is almost low range from 1000 to 1800 meters above sea level (Kangalawe et al., 2012). The minimum temperature is $19^{\circ} \mathrm{C}$ (June to July) while the maximum is $35^{\circ} \mathrm{C}$ (August to December) (Kangalawe et al., 2012). The average rainfall is $600 \mathrm{~mm}$ per year, which falls between December and April and hence the district is vulnerable to water scarcity (Kayombo, 2016; Sirima, 2016). This explains the prevalence and high prominence of groundwater use, which is extracted from shallow-wells and boreholes (Pavelic et al., 2012).

The study employed sequential exploratory research design with two phases. Phase one involved qualitative data collection and analysis. The results from phase one were used to refine questions in the questionnaire used as data collection tool during phase two. The second phase used household survey to collect quantitative data. Focus Group Discussions (FGDs) and key informant interviews guided by checklist of items were used to collect qualitative data. The study population involved groundwater users in the selected villages. The sampling procedures involved purposive selection of three villages using criteria including availability of groundwater infrastructures. Three villages including Nyeregete, Ubaruku and Mwaluma from Rujewa, Ubaruku and Ihahi wards respectively were purposively selected (Figure 1). A total of 30 groundwater users from each village were randomly selected making a sample size of 90 respondents. This sample size is considered appropriate because it allows statistical analysis leading to reasonable conclusions (Bailey, 1994).

One FGD was conducted in each village making a total of three FGDs. Sex and age were the criteria used to select FGDs participants. These criteria were useful to get different experiences and perceptions on groundwater use conflicts from men and women and also from different age groups. A total of 32 groundwater users participated in FGDs and $53 \%$ of the participants were women. The size of FGDs ranged between 8 and 12 participants as recommended in the literature. The proportion of women FGDs participants ranged from 5 to 7 in each group. Women were involved in FGDs because they are primary water stakeholders responsible for collecting water at a household level. The information gathered during FGDs captured an existence of groundwater conflicts, parties involved in the conflicts and conflicts resolution. The Village Executive Officers (VEOs) from each village, the chairperson and secretary of Ubaruku Mpakani (UBAMPA), a Community Water Supply Organization (COWSO), were involved as key informants.

The key informant interviews were also conducted to obtain information on the existence of groundwater conflicts, parties involved in the conflicts and conflicts resolution. The key informants were selected based on the fact that they are responsible to influence positive relationship in water governance structures at different administrative levels. In addition, household survey guided by a questionnaire was used to quantify demographic characteristics, experience on groundwater use conflicts, parties involved in the conflicts, and groundwater use conflict resolutions. Content analysis was used to analyze qualitative data by summarizing field data based on objectives of the study. Quantitative data were summarized by using Statistical Package for the Social Sciences (SPSS) by computing descriptive statistics to obtain frequency and percentage distribution of the respondents' responses.

\section{Respondents' characteristics}

Respondents' characteristics are presented in Table 1. The analysis shows that $58.9 \%$ of the respondents were household heads. The rest were spouses and other household members. In addition, $62.2 \%$ of the respondents depended on farming activities as their main source of income followed by $18.9 \%$ who depended on small scale businesses. This implies that majority of the respondents were smallholder farmers. The crops cultivated in the study area are: paddy, maize, sunflowers and groundnuts. The study area is also known in producing vegetable crops like onion and watermelon. In Tanzania, more than $70 \%$ of the Tanzania work force depends on agricultural sector for the livelihoods (Lwoga et al., 2011).

Respondents' responses on other sources of income apart from what is considered as a main source are presented in Table 2 . The analysis shows that $37.8 \%$ of the respondents reported livestock keeping. The rest reported casual labour, remittance and small scale business as their households' supplementary sources of income. Livestock keeping and crop production as sub sectors are the leading households' other sources of income. This implies that majority depended on farming and or livestock keeping in supporting their livelihoods. Table 3 summarizes respondents' marital status and education levels. Overall, the results show that $72.2 \%$ of the respondents were married. Out of married couples, $80 \%$ were males. With regard to the respondents' education level, $53.3 \%$ of the respondents held primary education. This implies that majority had acquired basic education.

Education is imperative for economic development in a society. This includes knowledge, skills, values and attitudes (URT, 2000). Thus, low education level may affect the use of groundwater at a household level. Table 4 shows respondents' age, household size, total number of years a household resided in the village and household annual income. The mean age of the respondents was 43 years. This implies that the sample comprised potential workforce for households' socio-economic development. Furthermore, the mean number of persons per household was 5.9. This is above 4.9 persons reported at the national level (United Nations World Food Programme and World Bank, 2013). Larger household size has implications on the amount of groundwater used at a household level.

With regard to the total number of years in which respondents resided in the village; the mean number was 18.4 years. This implies that respondents had enough experience with regard to water resource in the villages. The results also show that the mean households' annual income was Tanzania Shillings (TZS) $3,074,500$, equivalent to TZS 256,208 per month per household (Table 4). This amount is higher than the mean income at a national level. Literature shows that the mean household income is TZS 146,000 per month per household in Tanzania (URT, 2012). The higher household income in the study area, relative to the national level, is attributed to potential socio-economic activities including paddy production that are undertaken in the Usangu plain including Mbarali District. Households with higher income are capable to paying for groundwater charges with implication to improved 


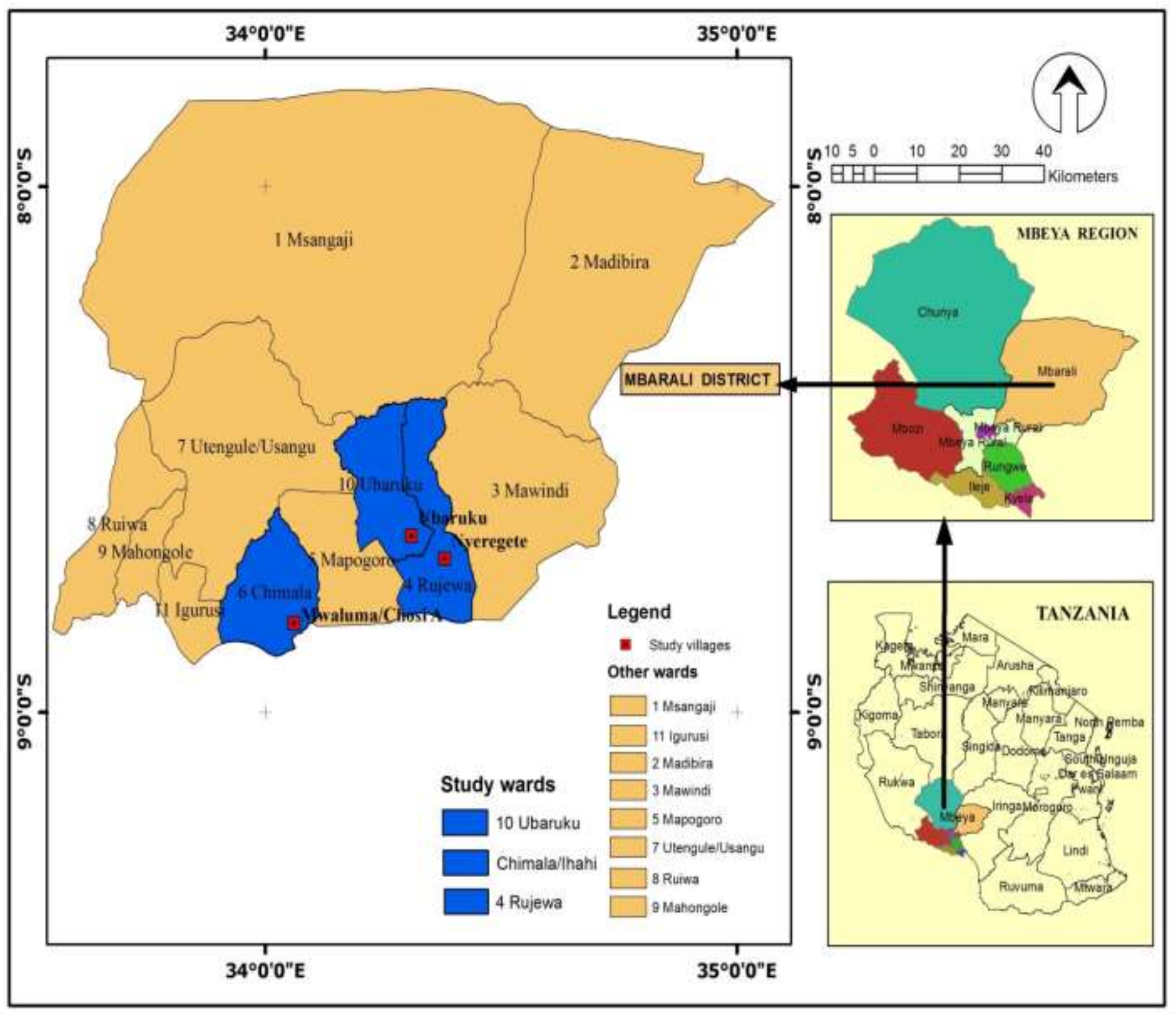

Figure 1. Map of Mbarali District showing study villages (Source: Gudaga et al., 2018a).

livelihoods.

\section{RESULTS AND DISCUSSION}

\section{Trends in groundwater use conflicts and or disputes}

This article defines conflict as disagreement between the parties whether individuals or governance structures and institutions that develops into violent actions like physical fighting. The article refers to disputes if disagreement does not develop into violent actions. Table 5 presents respondents' responses on the period when they experienced groundwater use disagreements in their villages.

The results show that $47(52.2 \%)$ of the respondents did not experience groundwater use disagreements at all, majority of them were from Mwaluma and Nyeregete. However, this does not mean that there was completely no disagreements because, overall, $43(47.7 \%)$ of the respondents reported having experienced groundwater use conflicts in the previous five years since 2013. Most $13(43.3 \%)$ of the conflicts were reported in Ubaruku particularly between the Village Councils and the Community Water Supply Organizations (COWSOs). These are groundwater governance structures expected 
Table 1. Respondents' characteristics $(n=90)$.

\begin{tabular}{lcccc}
\hline Characteristics & Nyeregete & Ubaruku & Mwaluma & Total \\
\hline Sex & & & & \\
Male & $15(50)$ & $15(50)$ & $15(50)$ & $45(50)$ \\
Female & $15(50)$ & $15(50)$ & $15(50)$ & $45(50)$ \\
Relationship to the Household head & & & & \\
Head of household & $22(73.3)$ & $16(53.3)$ & $15(50)$ & $53(58.9)$ \\
Spouse & $7(23.3)$ & $8(26.7)$ & $15(50)$ & $30(33.3)$ \\
Another Male Household member & $0(0.0)$ & $3(10)$ & $0(0.0)$ & $3(3.3)$ \\
Another Female Household member & $1(3.3)$ & $3(10.0)$ & $0(0.0)$ & $4(4.4)$ \\
Main source of income & & & & \\
Farming yield & $20(66.7)$ & $20(66.7)$ & $16(53.3)$ & $56(62.2)$ \\
Livestock keeping & $1(3.3)$ & $2(6.7)$ & $1(3.3)$ & $4(4.4)$ \\
Small scale business & $6(20.0)$ & $7(23.3)$ & $4(13.3)$ & $17(18.9)$ \\
Casual labour & $0(0.0)$ & $0(0.0)$ & $2(6.7)$ & $2(2.2)$ \\
Salary & $3(10.0)$ & $1(3.3)$ & $7(23.3)$ & $11(12.2)$ \\
\hline
\end{tabular}

Numbers in brackets are percentages.

Table 2. Other sources of income $(n=90)$.

\begin{tabular}{lcccc}
\hline Source of income of the household & Nyeregete & Ubaruku & Mwaluma & Total \\
\hline Farming & $5(16.7)$ & $5(16.7)$ & $9(30)$ & $19(21.1)$ \\
Livestock keeping & $10(33.3)$ & $13(43.3)$ & $11(36.6)$ & $34(37.7)$ \\
Casual labour wages & $9(30)$ & $3(10)$ & $5(16.7)$ & $17(18.9)$ \\
Remittances & $3(10)$ & $1(3.3)$ & $2(6.7)$ & $6(6.7)$ \\
Small scale business & $3(10)$ & $5(10)$ & $0(0)$ & $8(8.9)$ \\
None & $0(0)$ & $3(10)$ & $3(10)$ & $6(6.7)$ \\
Total & $30(100.0)$ & $30(100.0)$ & $30(100.0)$ & $90(100.0)$ \\
\hline
\end{tabular}

Numbers in brackets are percentages.

Table 3. Respondents' marital status and education level $(n=90)$.

\begin{tabular}{lccc}
\hline Status & Male & Female & Total \\
\hline Marital status & & & \\
Married & $36(80.0)$ & $29(64.4)$ & $65(72.2)$ \\
Single & $4(8.9)$ & $2(4.4)$ & $6(6.7)$ \\
Divorced & $1(2.2)$ & $5(11.1)$ & $6(6.7)$ \\
Widowed/widower & $4(8.9)$ & $9(20.0)$ & $13(14.4)$ \\
& & & \\
Education level & $10(22.2)$ & $8(17.8)$ & $18(20.0)$ \\
Non-formal education & $26(57.7)$ & $22(48.9)$ & $48(53.3)$ \\
Primary education & $3(6.7)$ & $12(26.7)$ & $15(16.7)$ \\
Secondary & $3(6.7)$ & $2(4.4)$ & $5(5.6)$ \\
Tertiary education & $3(6.7)$ & $1(2.2)$ & $4(4.4)$ \\
Higher Learning education & & &
\end{tabular}

Numbers in brackets are percentages.

to play part in resolving water conflicts. Being in conflicts themselves suggests ineffectiveness in discharging their duties for the betterment of the communities, and therefore requires intervention. The conflicts reported in 
Table 4. Descriptive statistics on respondents' characteristics.

\begin{tabular}{lcccc}
\hline Category & Minimum & Maximum & Mean & Std. Deviation \\
\hline Age of the respondent & 22 & 72 & 43.2 & 12.1 \\
Number of people in the household & 2 & 11 & 5.9 & 1.8 \\
Number of years the household heads resided in a village & 3 & 50 & 18.4 & 10.9 \\
Annual household income & 350,000 & $15,000,000$ & $3,074,500$ & $3,177,319$ \\
\hline
\end{tabular}

Table 5. Respondents' responses on when they experienced groundwater use conflicts $(n=90)$

\begin{tabular}{|c|c|c|c|c|c|}
\hline \multirow{2}{*}{\multicolumn{2}{|c|}{ When conflict/dispute occurred? }} & \multicolumn{3}{|c|}{ Village name } & \multirow[b]{2}{*}{ Total } \\
\hline & & Nyeregete & Ubaruku & Mwaluma & \\
\hline Did not ex & & $15(50.0)$ & $10(33.3)$ & $22(73.3)$ & $47(52.2)$ \\
\hline \multirow{4}{*}{ This year } & & $5(16.7)$ & $5(16.7)$ & $2(6.7)$ & $12(13.3)$ \\
\hline & One to two years ago & $2(6.7)$ & $13(43.3)$ & $6(20)$ & $21(23.3)$ \\
\hline & Three to five years ago & $7(23.3)$ & $2(6.7)$ & $0(0.0)$ & $9(10.0)$ \\
\hline & More than five years ago since 2013 & $1(3.3)$ & $0(0.0)$ & $0(0.0)$ & $1(1.1)$ \\
\hline Total & & $30(100.0)$ & $30(100.0)$ & $30(100.0)$ & $90(100)$ \\
\hline
\end{tabular}

Numbers in brackets are percentages.

this study were disagreements that did not develop into violent actions and therefore qualifying to be groundwater use disputes rather than conflicts.

Some disagreements occurred unnoticed by governance structures like Village Councils. For example, during key informant interviews in Nyeregete village it was reported that there were no cases related to groundwater disagreements, which were reported by groundwater users at the Village Government Office as shown in the following quotation:

"..I have been in this office for almost three years now, I have never received any complain from my villagers related with groundwater disagreement. I do not know if there are disagreements at their water points. Perhaps they are resolved at the groundwater users' level..."

The quotation aforementioned contradicts quantitative results that revealed groundwater disputes. This can be explained by the fact that groundwater disagreements were resolved by water users themselves possibly without information at the Village Council. Unlike conflicts related to surface water in Tanzania, groundwater disputes were not that much serious in the study area. Surface water related conflicts are attributed to various factors including massive abstraction for agricultural activities without proper management (Sokile et al., 2005). Groundwater is not a main source of water for agricultural production in the study area, but it is critical for domestic use like drinking, watering animals and paddy nurseries, cooking, washing and bricks making. This is justified by one of the key informants in the following quotation:
"Groundwater is not used intensively for irrigation activities rather it is for domestic purposes"

Based on that quotation, one can associate the disputes related to groundwater use with little utilization of the resource in agricultural production. Another reason is weak groundwater governance structures and institutions particularly policies, rules, and regulations that are reported to be not effective relative to informal ones like norms, values and customs (Gudaga et al., 2018b). Yet, as long as the use of groundwater for domestic use is essential livelihoods (Villholth, 2013), effectiveness of groundwater governance is required to reduce or avoid the possible groundwater use disputes that, according to the trends in Table 5, could increase and develop into conflicts in future.

\section{Parties involved in groundwater disputes}

Overall, the results show that $60.5 \%$ of the respondents reported that disagreements occurred between and among groundwater users themselves (Table 6). There was however differences in responses on the parties involved between the villages. For instance, looking at Nyeregete and Mwaluma villages, $93.3 \%$ and $87.5 \%$ of the respondents respectively reported between and among groundwater users while in Ubaruku village $75 \%$ of the respondents reported between and among governance structures responsible for water governance. This implies that groundwater disagreements occurred at different levels: first at the water users' level when accessing the resource from water points, and secondly, 
Table 6. Respondents' responses on parties involved in groundwater conflicts $(n=43)$.

\begin{tabular}{lcccc}
\hline Parties involved & Nyeregete & Ubaruku & Mwaluma & Total \\
\hline Structures responsible for water management and conflict resolution & $1(6.6)$ & $15(75)$ & $1(12.5)$ & $17(39.5)$ \\
Groundwater users themselves & $14(93.3)$ & $5(25)$ & $7(87.5)$ & $26(60.5)$ \\
Total & $15(100)$ & $20(100)$ & $8(100)$ & $43(100)$ \\
\hline
\end{tabular}

Numbers in brackets are percentages.

Table 7. Respondents' responses on causes of groundwater disputes $(n=90)$.

\begin{tabular}{lcccc}
\hline Causes of disputes & Nyeregete & Ubaruku & Mwaluma & Total \\
\hline Restriction of water use & $5(33.3)$ & $0(0.0)$ & $1(12.5)$ & $6(13.9)$ \\
Restriction of water distribution to the households & $0(0.0)$ & $9(45)$ & $0(0.0)$ & $10(23.3)$ \\
Destruction of water points & $10(66.7)$ & $0(0.0)$ & $7(87.5)$ & $17(39.5)$ \\
Lack of transparency on financial report & $0(0.0)$ & $11(55)$ & $0(0.0)$ & $10(23.3)$ \\
Total & $15(100)$ & $20(100)$ & $8(100)$ & $43(100.0)$ \\
\hline
\end{tabular}

Numbers in brackets are percentages.

at an institutional level. For example, participants during FGDs in Ubaruku village reported misunderstandings between COWSO and the Village Council, herein also referred to as the Village Government. This is justifies in the follow quotation:

"...COWSO is made of 5 representatives including chairpersons from hamlets of our village. It is supposed to fulfil its responsibilities under the Village Council control by providing plans, and financial reports. Unfortunately, COWSO works in isolation from the Village Council..."

One of the key informants also reported that:

"....COWSO is a registered organization by the Mbarali District Council. Thus, it provides reports to the district water department and the department makes consultation to the COWSO so as to ensure that groundwater service is accessible to all people and it remains sustainable..."

The quotations above justify that there were disagreements between water governance structures in a way of discharging their roles. This is attributed to limited information on the responsibilities of the governance structures as stipulated in the Water Resource Management Acts (WRMA) no 11 and 12 of 2009. The Acts stipulate that COWSOs should be accountable to the Village Councils. It is clear that poor stakeholders' participation, inadequate communication among water stakeholders contribute to difficulties in achieving collective responsibilities to manage water resource including resolving water disputes. A good thing is that WRMAs stipulate that COWSOs should provide financial reports to the Village Councils, which should in turn present the reports to the Village Assembly. The Acts assign the District Councils responsibility of registering COWSOs and providing technical support to them. This does not shift the accountability of the COWSOs to the Village Councils. Thus, groundwater stakeholders and water governance structures should understand apparently and functions according to the WRMAs to avoid disputes (Braune and Xu, 2008).

\section{Causes of groundwater disputes}

Overall, $17(39.5 \%)$ of the respondents reported that groundwater disputes between and among water users occurred due to destruction of groundwater points particularly water pumps. Other factors include lack of transparency on financial reports and restriction of water distribution to the households for some reasons. Interestingly, the causes differed by villages. For instance, $66.7 \%$ and $87.5 \%$ of the respondents in Nyeregete and Mwaluma respectively reported destruction of groundwater points as major cause of disputes in their villages (Table 7). Looking at the column for Ubaruku village, $55 \%$ and $45 \%$ of the respondents reported lack of transparency on groundwater related financial reports and restriction of water distribution to the households respectively (Table 7). Quantitative results were in line with qualitative results. For example, in one of the FGDs it was reported that COWSO was not presenting financial reports to the groundwater users implying lack of transparency and therefore poor effectiveness of COWSOs in discharging the duties as shown in the quotation below:

"....there is water charge regulation that requires every groundwater user to pay TZS 25 per bucket of water to the COWSO through the water agent at the water point to 
improve water service in the village. Although water service is good... the COWSO do not present financial reports to us as groundwater users. This creates distrust of groundwater users to the COWSO's leadership..."

One of the key informants reported, in relation to lack of transparency, the COWSO's leadership had no legal power to call for a Village Assembly so as to present financial reports related to groundwater governance as shown in the quotation:

"...COWSO operates closely with the groundwater users by improving water service using available financial resource. I know the importance of presenting financial reports to the groundwater users but the problem is that the Village Council does not allow us to call for public meetings and even during the routine Village Assembly, the Village Council do not give us an opportunity to present the reports.."

Furthermore, through key informant interviews, the study found that it was not the intention of the Village Councils to threaten efforts of the COWSO on groundwater issues as follows:

"...I acknowledge that COWSO is doing a good job on groundwater governance in this village. But there are conflicts on water governance between the COWSO and the Village Council. This groundwater project was donated for 95\%, 2.5\% and 2.5\% by the World Bank, Village Council and the communities respectively. The Village Council facilitated establishment of COWSO to enhance groundwater governance in the village. Thus, the COWSO has to work under the Village Council control. Unfortunately, the claim of COWSO that it is an independent organisation since it is registered to the district authority discourages the Village Council to support it..."

Based on these contradictory explanations, the article argues that groundwater governance structures lack comprehensive understanding on how to fulfil their responsibilities. In fact, what is missing is awareness about the procedures in discharging the duties of the COWSO as reported by Gudaga et al. (2018a). Principally, the COWSOs should present financial reports to the Village Councils for discussion and accountability. The Village Councils are governance structures responsible to call for a Village Assembly where issues of income and expenditure related to groundwater use can be discussed transparently with groundwater users. Therefore, awareness creation about the procedures of discharging the duties is imperative among groundwater governance structures and groundwater users.

\section{Governance structures involved in resolving disputes}

With regard to dispute resolution, the results show that
$53.4 \%$ of the respondents reported that groundwater users were mainly involved (Table 8). In most cases, disputes were resolved without notice to the Village Councils when the offender pays fine or rehabilitate the well based on the rules and regulations in place. This is in line with qualitative data. For example, during FGD participants reported that most of the disagreements were resolved by groundwater users themselves.

"...some groundwater users destroy water pumps in the process of pumping water. Unfortunately, some of them are rude and not willing to be rebuked by their fellow groundwater users for their non acceptable behaviour. That behaviour leads to disagreements at the water points. But a good thing is that we resolve disagreements without involving the Village Council..."

This quotation justifies that groundwater users themselves have a great role to resolve disputes at a local level. This is attributed to effectiveness of informal institutions to govern water resource as reported by Gudaga et al. (2018a).

However, this does not rule out what is reported in the literature that a successful strategy of resolving and preventing water conflicts and or disputes requires institutional capacity building of formal institutions (Petersen-Perlman et al., 2017). This implies that formal institutions should work in a coordinated way with informal ones to resolve groundwater disputes between the parts involved (Table 8). There were differences between the villages in terms of who resolves groundwater disputes. For instance, in Ubaruku village $50 \%$ of the respondents reported that COWSO leaders and Village Council respectively were involved (Table 8).

Table 9 summarizes status of groundwater disputes resolution. Overall, $67.4 \%$ of the respondents reported that the disputes were resolved successfully. Nevertheless, there were differences about the success in resolving disputes between the villages. Taking an example of Nyeregete and Mwaluma villages, the results show that $100 \%$ of the respondents reported that the disputes were resolved successfully compared to $70 \%$ of the respondents in Ubaruku who reported the same. It is clear that disagreements between the COWSO and the Village Council reported in section 4.3 and 4.4 in this article were difficult to resolve and have serious consequences to the groundwater users as reported during FGDs:

"...Groundwater users pay water charges at the water point per bucket (20 litres), but we have never received the reports of those collections because of the disagreements existing between the COWSO and the Village Council. The disagreements between these parties affect transparency and accountability on groundwater governance in our village..."

In addition to controlling conflicts and disputes, 
Table 8. Governance structures involved in resolving disputes $(n=43)$.

\begin{tabular}{lcccc}
\hline Structures & Nyeregete & Ubaruku & Mwaluma & Total \\
\hline COWSO leaders & $0(0.0)$ & $10(50)$ & $0(0.0)$ & $10(23.3)$ \\
Village council & $0(0.0)$ & $10(50)$ & $0(0.0)$ & $10(23.3)$ \\
Groundwater users & $15(100)$ & $0(0.0)$ & $8(100)$ & $23(53.4)$ \\
Total & $15(100)$ & $20(100)$ & $8(100)$ & $43(100)$ \\
\hline
\end{tabular}

Table 9. Respondents' responses on status of resolving disputes successfully ( $n=43)$.

\begin{tabular}{lcccc}
\hline Disputes resolution & Nyeregete & Ubaruku & Mwaluma & Total \\
\hline Resolved successfully & $15(100)$ & $6(30)$ & $8(100)$ & $29(67.4)$ \\
Not resolved successfully & $0(0.0)$ & $14(70)$ & $0(0.0)$ & $14(32.5)$ \\
Total & $15(100)$ & $20(100)$ & $8(100)$ & $43(100)$ \\
\hline
\end{tabular}

Numbers in brackets are percentages.

groundwater governance is also important for water quality control. Groundwater is a natural resource and a public good in Tanzania. For a matter of governance, water users must pay for the resource even if individuals dig and construct wells using their own cost. The government should intervene in terms of expertise especially on where about one can dig and construct a well. Participants, during Focus Group Discussions, reported that most of the groundwater users had inadequate knowledge on how and where to construct groundwater wells at a household level as shown in the following quotation:

"...We use our own indigenous knowledge to dig wells around our homes...but most of us are not aware about the proper distance from pit latrines to a groundwater well..."

That quotation suggests that there was no control regarding groundwater pollution to ensure water quality. Literature recommends that the bottom of pit latrines should be at least 2 meters underground, and a minimum horizontal distance of 30 meters between a pit latrines and a groundwater well. This recommendation aims to limit exposure to microbial contamination (Fenner et al., 2007; Foster et al., 2016).

\section{CONCLUSION AND POLICY RECOMMENDATIONS}

Based on the results and discussion, the article concludes that it's disputes rather than conflicts that were happening. While disputes were likely to increase, they could also develop into conflicts in the future if they continue unabated. The disputes occurred at two levels: first, at water users, and secondly, at institutional level between governance structures. This made resolution of groundwater disputes difficult because groundwater governance structures who are key actors in resolving disputes were also in disagreements themselves. The Village Councils and COWSOs were in disagreement because of lack of awareness of the procedures to discharge their duties. Generally, disputes occurred because of poor awareness and failure to abide to rules and regulations stipulated in the Water Resource Management Acts of Tanzania. Therefore, governance structures were not effective in resolving disputes. Based on the conclusions, the article recommends awareness creation about the procedures on discharging the duties among groundwater governance structures and groundwater users. This is the responsibility of the Water Board Offices and district authorities. Strengthening of the governance structures in abiding to the Acts is also recommended. The article also recommends development of a comprehensive framework in terms of governance structural set up, formal and informal institutions to resolving groundwater use disputes.

\section{ACKNOWLEDGEMENT}

This study was financed by Grofuture project whereas its overall aim was to develop scientific basis and participatory management processes by which groundwater resources can be used sustainably for poverty alleviation in Sub-Saharan Africa for which the authors are thankful.

\section{CONFLICT OF INTERESTS}

The authors have not declared any conflict of interests.

\section{REFERENCES}

Bailey KD (1994). Methods of Social Research. Free Press, New York P 588. 
Braune E, Xu Y (2008). Groundwater management issues in Southern Africa an IWRM perspective. [http://www.wrc.org.za] site visited on $18 / 07 / 2017$

Earth Security Group (2016). Global Depletion of Aquifers: Global companies must take an active role in groundwater governance to avoid existential risks. [https://earthsecuritygroup.com/wpcontent/uploads/2016/06/ESG-Brief-Aquifers.pdf ] site visited on $24 / 05 / 2018$

Facius JL (2008). Water scarcity in Tanzania - conflict or cooperation? An analysis of the relationship between institutions and local water conflict and cooperation. Master Thesis International Development Studies P 104.

Fenner RA, Guthrie PM, Piano E (2007). Process selection for sanitation systems and wastewater treatment in refugee camps during disaster-relief situations. Water and Environment Journal 21(4):252-264.

Foster S, Garduno H (2013). Groundwater-resource governance: Are governments and-stakeholders responding to the challenge? Hydrogeology Journal 21(2):317-320.

Foster T, Brozović N, Butler AP (2016). Effects of initial aquifer conditions on economic benefits from groundwater conservation. Water Resources Research 53(1):744-762. [https://doi.org/10.1002/2016WR019365]

Gudaga JL, Kabote SJ, Andrew KPR, Tarimo AKPR, Mosha DB, Kashaigili JJ (2018a). Groundwater users' awareness of water institutions in Tanzania: A case study of Mbarali District, Mbeya Region. Journal of African Studies and Development 10(3):29-42.

Gudaga JL, Kabote SJ, Andrew KPR, Tarimo AKPR, Mosha DB, Kashaigili JJ (2018b). Effectiveness of groundwater governance structures and institutions in Tanzania. Applied Water Science 8(2):114.

Jarvis WT (2008). Strategies for Groundwater Resources Conflict Resolution and Management. In: Darnault C.J.G. (eds) Overexploitation and Contamination of Shared Groundwater Resources. NATO Science for Peace and Security Series C: Environmental Security. [https://doi.org/10.1007/978-1-4020-69857_19] site accessed on 24/12/2017.

Kangalawe R, Mwakalila S, Masolwa P (2012). Climate change impacts, local knowledge and coping strategies in the great Ruaha river catchment area, Tanzania. Natural Resources Journal 2:212223.

Kashaigili JJ (2010). Assessment of groundwater availability and its current and potential use and impacts in Tanzania.[http://gwafrica.iwmi.org/Data/Site/24 Sites/24/media/pdf/Country_ReportTanzania.pdf] site visited on 24 May, 2015.

Kayombo WC (2016). Assessing meteorological data for reference evapotransp iration in Kyela and Mbarali district. Journal of Environment and Earth Science 6(4):1-7.

Kweka-Msale C, Magina F (2009). Conflict Management in Rural Water Sources in Tanzania. FIG Working Week 2009, Surveyors Key Role in Accelerated Development Eilat, Israel, 3-8 May 2009.

Lwoga ET, Stilwell C, Ngulube P (2011). Access and Use of Agricultural Information and Knowledge in Tanzania. Library Review 60(5):383395.

Pavelic P, Giordano M, Keraita B, Ramesh V, Rao T (2012). Groundwater-availability and use in Sub - Saharan Africa.[http:www.cg

iar.org/Publications/Books/PDF/groundwater_availabilility_and_use_i n-subsaharan africa a review of 15 countries.pdf] site accessed on $23 / 6 / 2016$.

Petersen-Perlman JD, Jennifer C, Wolf A (2017). International water conflict and cooperation: challenges and opportunities, Water International DOI: 10.1080/02508060.2017.127604.
Robins NS, Fergusson J (2014). Groundwater scarcity and conflict managing hotspots. Earth Perspectives 1:6 [https://doi.org/10.1186/2194-6434-1-6] site visited on 23/5/2018.

Sirima A (2016). Social and economic impacts of Ruaha national park expansion. Open Journal of Social Sciences 4:1-11.

Sokile CS, Mwaruvanda W, Koppen B (2005). Integrated Water Resource Management in Tanzania: Interface between formal and informal institutions. [http://www.sciepub.com/reference/188029] site visited on $3 / 5 / 2016$

Tuinhof A, Foster S, Steenbergen F, Talbi A, Wishart M (2011). Appropriate Groundwater Management Policy for Sub-Saharan Africa in face of demographic pressure and climatic variability. Thematic Paper No.5, Sustainable Groundwater Management Contributions to Policy Promotion. GW MATE, World Bank, Global Water Partnership and Water Partnership Program.

United Nations Environmental Security (2004). Water, Conflicts and Cooperation Policy Brief. [https://www.wilsoncenter.org/sites/default/files/ecspr10_unfcaribelko.pdf] site accessed on 12/01/2017.

United Nations World Food Programme and World Bank (2013). Comprehensive Food Security and Vulnerability Analysis (CFSVA), Tanzania, 2012. Available: [http://www.UN-WorldFoodProgrammeandWorldBank2013.pdf] site accessed on 28/04/2017.

United Republic of Tanzania (URT) (2014). Mbarali District Council Strategic Plan 2013/14-2017-18; Prime Minister's Office Regional Administration and Local Government. [http://www.mbaralidc.go.tz/storage/app/uploads/public/58d/10/58d10 1fccce7f653574057.pdf] site visited 27 September, 2017.

United Republic of Tanzania (URT) (2012). National Baseline Survey Report for Micro, Small, and Medium Enterprises in Tanzania. [MSME-National-Baseline-Survey-Report.pdf] site accessed on $16 / 03 / 2017$.

United Republic of Tanzania (URT) (2000). Education in a Global Era: Challenges to Equity, Opportunity for Diversity. Paper presented at the Fourteenth Conference of Commonwealth Education Ministers (14 CCEM) Halifax, Nova Scotia, Canada pp. 27-30.

Villholth KG, Tottrup C, Stendel M, Maherry A (2013). Integrated mapping of groundwater drought risk in the Southern African Development Community (SADC) Region. Hydrogeology Journal 21(4):863-885.

Wijnen M, Benedicte A, Bradley H, Ward C, Huntjens P (2012). Managing the Invisible- Understanding and Improving Groundwater Governance. Thematic Paper No.11, Groundwater Governance, A Global Framework for Action. GEF, World Bank, UNESCO-IHP, FAO and $\mathrm{IAH}$. 